DOI: $10.2478 /$ pof-2018-0010

VOLUME 10, ISSUE 1, 2018

ISSN: $2036-5438$

\title{
Socialisation and legitimacy intermediation in the Council of the European Union
}

by

Kamil Ławniczak*

Perspectives on Federalism, Vol. 10, issue 1, 2018 


\section{Abstract}

The Council is a crucial intergovernmental institution of the European Union. However, the complex, opaque and consensual character of the decision-making process in the Council puts its legitimacy into question. Intergovernmentalist theory posits that it is sufficiently legitimised, indirectly, by the member state governments. Constructivist research, on the other hand, suggests that socialisation might disturb the relaying of positions from the national to the supranational level, as the former approach implies.

This paper aims to explore these issues, in particular related to representation and consensus. It contains an analysis of material generated in in-depth interviews and concludes that more effort is invested into reaching a more inclusive compromise in the Council than one would expect if it were to decide by qualified majority. Socialisation is weakening the input legitimacy of decisions made in the Council, while at the same time enhancing their output legitimacy by favouring genuine consensus.

\section{Key-words}

indirect legitimacy, input legitimacy, output legitimacy, consensus, national officials 


\section{Introduction}

The Council is at the centre of the decision-making process in the European Union (EU), both in legislative and non-legislative matters. Empirical research on how the Council decides is well-established in the literature; it tackles various issues such as voting power (e.g. Thomson 2010), coalition formation (e.g. Mattila 2010), communication patterns (e.g. Beyers and Dierickx 1998), socialisation (e.g. Lewis 2007), transparency (e.g. Laursen 2013). Research suggests that the Council is neither solely a place of typical interstate bargaining, nor a second chamber of a EU federal assembly united by a common understanding of European interests. This ambiguous status, accompanied by wide decision-making powers, puts into question the relevant sources and mechanisms of legitimacy.

The intergovernmentalist approach (Moravcsik 2002, 2008) argues that the indirect legitimacy conferred by member states is sufficient for the European Union, especially when it is coupled with output-oriented legitimising arguments. One assumption behind this reasoning, which seems to be particularly important, is that intergovernmental EU institutions function as undisturbed relays of positions established within national political systems. The positions are transferred (via instructions) to the EU level, where intergovernmental negotiations take place and agreement is reached. Thus, the accountability and legitimacy of EU decision-making can be traced back to the parliamentary accountability of governments and the democratic input legitimacy of national political systems.

However, many scholars, in particular constructivists, do not share such an understanding of the EU's political processes. Constructivist research on decision-making in EU institutions suggests that social processes which occur in intergovernmental EU institutions might disturb the relaying of positions described above (Aus 2010; Lewis 2010b; Juncos and Pomorska 2011). This begs the question of how these disruptions affect the problem of legitimacy. In this regard, a normative inquiry regarding the democracy and legitimacy of the EU needs empirical research, to clarify the extent to which socialisation influences legitimacy intermediation, as well as the character of the disruptions it supposedly causes. Moreover, because of the apparent consensual quality of decision- 
making in the Council, it is important to inquire into the meaning of consensus in this regard and the ways it is reached.

The objective of this paper is to establish links between empirical research on socialisation and decision-making in the Council, and normative questions regarding democracy and legitimacy of governance at the EU level. In order to do so, the paper first outlines the characteristic features of decision-making in the Council, in particular its complexity, lack of transparency and the prevalence of consensus, despite an increasing scope of issues which could be decided by qualified majority. The third section then enquires into the role the Council plays in providing legitimacy to the $\mathrm{EU}$, and the fourth describes the potential consequences of socialisation of national officials in the Council. The remainder of the paper aims to answer two research questions by analysing empirical material generated in in-depth interviews: first, how can legitimacy intermediation through the Council be disrupted by normative and behavioural changes among socialised national officials? Second, does the process of reaching consensus in the Council help provide output legitimacy, or undermine it? The paper concludes by summarising the results and discussing them, which directs to further questions and avenues for research.

\section{Decision-making process in the Council: complex, opaque, consensual}

The decision-making process in the Council is highly complex; its features result from several factors - the three most important concern the structural characteristics of the Council and its engagement in shaping EU decisions. First, the Council deals with a wide variety of matters, which requires a horizontal division of labour, i.e. there are diverse bodies (or multiple individual configurations of a formally singular body) for different substantial policy areas. Second, the Council is a multi-layered structure composed of numerous organs: from working parties and committees up to ministerial configuration. The former, called preparatory bodies, gather national officials of different ranks and act as filters to ensure that latter (the ministers who constitute the top layer, or the Council in the strict sense) only have to deal with issues that would not find a reasonable solution without their engagement (Häge 2008; Kirpsza 2011; Grøn and Salomonsen 2015). Third, decisionmaking in the EU has become more complicated as a result of the developments of 
European integration: the European Parliament (EP) plays a more important role, the number of member states is growing, and so is the scope of EU policies. These changes have caused the Council to expand its informal procedures, and similar processes can be observed in interinstitutional relations (Fabbrini and Puetter 2016).

Despite the complexity of its structure, functions and relations, the Council is a productive decision-maker; member states reach agreement by trading concessions, persuasion, finding compromise solutions to common problems, allowing for opt-outs or exceptions, or delegating details to the implementation phase (Warntjen 2017: 966-967). The relative importance of each of these (and other) approaches is debated in the literature. Some authors distinguish several normative modes of negotiation, which differ in the extent of cooperative behaviour between the parties and might depend on substantive, issue-specific, or institutional structural factors (Warntjen 2010; Cross 2012). Others analyse variation among the actors, e.g. how much do they rely on argumentation, how generous do they tend to be, or with whom do they cooperate most often (Naurin 2009, 2015; Naurin and Lindahl 2010).

One of the characteristics of the decision-making process in the Council which draws considerable attention is its lack of transparency. Despite pro-transparency reforms of the 1990s (Hillebrandt et al. 2014) the details of what takes place within the Council remain hidden from the public. The opacity is particularly pronounced in non-legislative issues, but manifests itself when the Council acts in its legislative capacity as well. In the latter case, transparency is reduced by a reliance on informal communication between the representatives of member states, and institutionalised, albeit informal, forums of either intra- or inter-institutional negotiation (e.g. Hillebrandt and Novak 2016; Reh et al. 2013). Much of the interest in transparency stems from the belief that it contributes to legitimacy, responsibility and accountability - or, more generally, from the idea that it is a constitutive part of democratic rule and good governance (Hillebrandt et al. 2014: 4-5).

On the other hand, parties sceptical towards transparency invoke the need for a 'space to think' away from an audience (Hillebrandt and Novak 2016: 527-529). They claim that without such space intergovernmental institutions would be unable to efficiently resolve issues facing the EU. In fact, some studies give credit to such notions, e.g. James Cross (2013) shows how transparency induces polarisation of negotiators positions, while Stéphanie Novak (2013: 1104) warns against deeper forms of secrecy, which could be 
devised in response to strong formal transparency provisions. Moreover, Jenny de Fine Licht and her colleagues' (2014) interesting experimental research casts doubt on the premise that increasing transparency of a decision-making process results in proportional increase in its legitimacy - a notion apparently substantiated by the continuous crisis of legitimacy of the EU.

Transparency is often studied along with the consensual quality of decision-making in the Council ${ }^{\mathrm{I}}$ - another feature of interest to many scholars and linked to the issue of legitimacy. Some decisions in the Council formally require unanimity, but a growing number of issues can be decided by qualified majority. However, the voting record shows much lower dissent than might be expected (König and Junge 2010), and while a government sometimes opposes a decision which does not fit its position, most of the time member states refrain from voting against it, or even abstaining (Høyland and Hansen 2014; Kleinowski 2012). In cases where unanimity is required, governments rarely block proposals (Smeets 2016).

One of the problems here is how to define consensus. There is a difference between unanimity as a method of taking decisions and consensus as either a process of negotiating compromise solutions, or an outcome in which no participant openly opposes a given proposal (Payton 2010; Novak 2013). The latter might be considered a minimal definition of consensus, but even then, the question of how is it attained remains. Why do the member states decide not to oppose decisions going against their interest?

Three major lines of explanation of prevalence of consensus in the Council can be distinguished in the literature. First, because member states have an interest in EU policies operating smoothly, they might prefer to avoid being blamed for obstructing the decisionmaking process, and also want to ensure that the decision will be implemented by all member states (Häge 2013: 485-486). To achieve this goal, they could engage in reciprocal concessions, including vote trading on specific issues, as well as more diffuse forms of reciprocity. In effect, they would be 'insured' against decisions violating their core interests (Naurin 2015). This might also be achieved by reducing precision in particular provisions, giving each member state more leeway in implementing EU policies (Tsebelis 2013), as well as by introducing exceptions or transitional periods suited to particular needs or expectations of a member state (Warntjen 2017). 
Second, the institutional organisation of decision-making in the EU might foster consensus in the Council. Externally, the Commission could be said to only introduce proposals which have a good chance of passing in the Council (Häge 2013: 485). Moreover, co-decision with the European Parliament could be an incentive for the member states to avoid showing internal disagreements, in order to be better positioned in inter-institutional negotiations (Hillebrandt and Novak 2016: 536-537). Internally, according to Frank Häge (2013), coalition building coupled with a high qualified majority threshold is producing consensus regardless of other considerations.

Third, many scholars who study consensus focus on relevant norms and their socialisation (Heisenberg 2005; Aus 2010; Häge 2013: 486; Lawniczak 2015). Such norms are often analysed as relating to cooperative behaviours among member state representatives during formal and informal stages of negotiation in the Council (Lewis 2010a; Smeets 2015; Kaniok 2016). There is also a current which explains consensus as a result of a deliberative mode of decision-making (Risse and Kleine 2010; Puetter 2016; Niemann 2010).

\section{The Council and EU legitimacy}

This paper builds on current research reviewed above, in particular taking into account consensus as a norm and practice within the complex structure of the Council. The focus in this section will turn to legitimacy. In short, legitimacy 'ensures voluntary compliance with unwelcome exercises of governing authority' (Scharpf 2007: 3). Because the Council is not directly elected or accountable to a European electorate, its legitimacy has to be derived from the legitimacy of each member state government. In other words, decisions taken by the Council are legitimised indirectly. This requires that both the legitimacy of the governments is undisputed, and that mechanisms exist which can guarantee successful intermediation of legitimacy by intergovernmental institutions (see below). Some authors argue that both could be assumed with sufficient certainty (e.g. Moravcsik 2002), while others contend this notion, claiming indirect legitimacy is inherently weak (e.g. Lord 2009).

Another way of looking at the problem is based on the distinction between input- and output-oriented legitimacy, developed by Fritz Scharpf (e.g. 2006). Such a distinction, which could also be related to notions on 'constraint' and 'capacity' (Lord 2009), underlines 
the dual nature of the relationship between those who govern and the people who are governed. The latter can only be expected to accept and comply with the former's decisions if they feel the holders of political power are somehow dependent on the people's voice (input) and willing to provide them with some kind of (tangible or intangible) benefits of their rule (output). The EU and its member states are conventionally seen as sharing these responsibilities: the member states provide input legitimacy through national politics and elections, while the EU ensures outputs such as higher living standards or opportunities resulting from the free movement of people.

A problem arises if either of these expectations is systematically not met. Vivien Schmidt (2006) calls this division of labour 'policy without politics' at the EU level, but also 'politics without policy' at the national level. If the member states are unable to solve their problems individually, their citizens expect EU action - if that fails, they become frustrated with such 'problem-solving gaps' (Scharpf 2009); as the gaps widen, the whole dual legitimising structure ceases to function properly. But even if the EU is successful in adopting common policies, the problem of 'selling' this output to the public remains, especially if it has a distributive impact, as most policies do, despite claims regarding the regulatory nature of many EU policy areas (Føllesdal and Hix 2006; cf. Majone 1998). The Council is a forum of special importance in this regard, as it (ideally) allows for the consideration of the specific constraints of each member state, and produces necessary justifications of adopted provisions (Clark and Jones 2011: 359).

However, the above-mentioned issues of informality and transparency become relevant here. The informal legislative negotiations which occur within the Council and between the Council, the EP and the Commission, are opaque and their participants remain largely unaccountable. Even if we consider the strong position of the directly elected EP in the latter meetings (Roederer-Rynning and Greenwood 2015), such informal decision-making, e.g. trilogues, does not meet minimal standards of democratic legitimacy (Reh 2014). As stated before, transparency might not be directly correlated with legitimacy, but there are theoretical and empirical arguments to expect some forms of (even limited) transparency as necessary to ensure legitimate decision-making (De Fine Licht et al. 2014). Consensus can also be seen as detrimental to accountability (Heisenberg 2005), but, as I argue below, it can contribute to legitimacy as well. 


\section{Socialisation of national officials}

Socialisation, 'a process of inducting actors into the norms and rules of a given community' (Checkel 2007: 5), is an important feature of the Council as a decision-making forum (or a structure composed of multiple interrelated forums). It is prominently mentioned in normative explanations of consensus, but what directs me towards it here is that it could potentially put into question one of the two assumptions on which indirect legitimacy stands, i.e. the effective transfer of results of national politics into EU policymaking.

Socialisation is a complex and ubiquitous social process, which occurs whenever individuals find themselves in a new social context - in particular an already established group of people. Social interactions between participants of such situations can lead the novice' to adopt relevant norms, roles or identities, or adapt their behaviour to fit into the community they interact with (Juncos and Pomorska 2011: 1098; Beyers 2010: 909). This process of (secondary) socialisation is not always successful: there are many factors which determine the extent of change of the behaviours and cognitive properties of the socialised individual.

Research conducted on European socialisation gives mixed results regarding its influence on identity or allegiance of national officials who regularly interact at the European level. While some results confirm the shift of such properties towards the EU (e.g. Drulák et al. 2003; Trondal 2004), most authors are cautious regarding this effect. They conclude that even if some sort of loyalty to the EU develops among officials working in the Council or other institutions, their allegiance to the nation state prevails (e.g. Juncos and Pomorska 2011: 1106).

More studies show a specific Council culture which manifests in practices, or behavioural changes among the staff of national permanent representations who take part in the decision-making process. Such adaptations in ways of doing things could, though, be the first step towards more in-depth normative shifts (Orbell et al. 1988: 811). Jeffrey Lewis's (2007) studies of Coreper show how both their practices and identities blend national and supranational components. Others see the national-oriented approaches as more fundamental - they frame and limit the subordinate EU- or cooperation-oriented practices (Chelotti 2016). The latter notion, that EU-oriented behavioural norms and 
practices are by definition cooperative, is shared in different studies, but remains unproblematised. In fact, successful socialisation does not equal the absence of conflict. Norms can sustain inequality, privilege, exclusion, hierarchy or domination (Beyers 2010: 912).

\section{Research questions and methods}

Taking into account the prior research presented above, the rest of this paper attempts to answer two questions pertaining to the issues of the indirect legitimation of Council decision-making and socialisation of Council officials. First, assuming national governments can provide input legitimacy, how can its intermediation through the Council be disrupted by normative and behavioural changes among socialised national officials? Second, if output legitimacy depends on EU institutions providing added value to the citizens, does the process of reaching consensus in the Council help such goal or undermine it? In other words, is it a genuine consensus built upon the (socialised?) notions of finding common interests and solving common problems, or is it a process aimed at reducing individual governments' accountability for decisions taken at the EU level, i.e. false or ingenuine consensus (which could also be sustained by socialised norms)? Put in a different, more critically-oriented frame, does it protect or subordinate the interests of the weaker member states?

The above questions posit two distinctions: between undisrupted and disrupted (input) legitimacy intermediation, and between genuine, and as such probably fostering outputlegitimacy, and ingenuine consensus. This way, there are four possible ideal-type scenarios of how socialisation can affect legitimacy, see Figure 1:

Figure 1. Potential effects of socialisation on legitimacy

\section{intermediation}

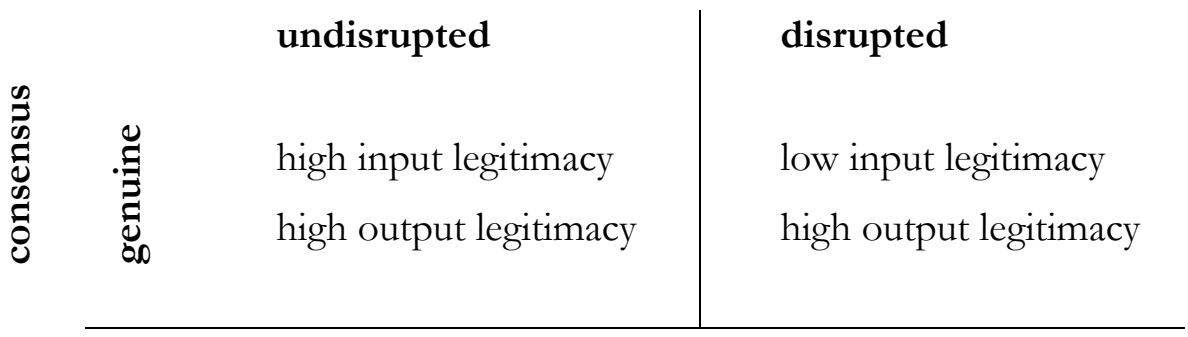




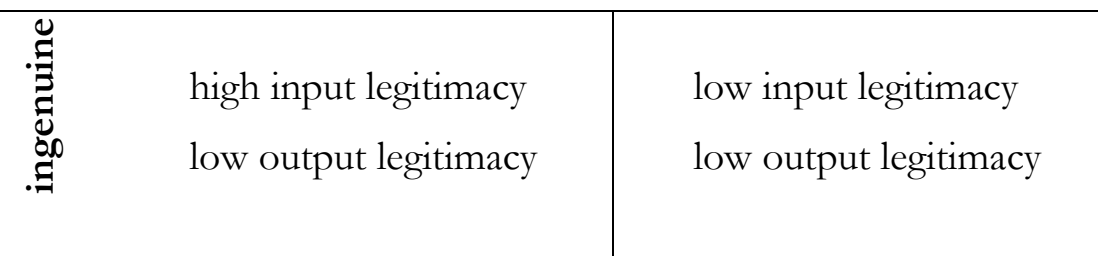

Below I undertake an explorative analysis of ten, in-depth, semi-structured interviews (see Appendix). The interviews were conducted in 2015 among officials who represented Poland at various bodies of the Council. Most of the interviewees worked at the Permanent Representation at the time of the interviews. They had at least three years of work experience in the Council (working parties, Coreper and ministerial configurations) and represented diverse policy areas.

My main objective here, which follows from the questions stated above, is to make sense of how actors in the Council decision-making process understand and act upon their representative roles and the notion of consensus. In order to do so, after close reading of the whole material, I developed a simple categorisation key based on the distinctions described above, which helped me determine whether the empirical material contained traces of either positive or negative legitimacy-related aspects of behavioural or normative adjustments or internalisations affecting Council officials in regard to representation and consensus. However, gravitating towards interpretive methodology (Schwartz-Shea and Yanow 2012), I remain open and flexible in the analysis, in order not to miss the meaningmaking of the interviewees and to capture the nuanced, implicit and contradictory elements of their statements. In the following section, I will quote the important parts of the interviews to aid such approach.

\section{Socialisation, representation and consensus}

As described above, socialisation affects individuals' behaviour as well as their properties (value judgements, roles, identities). My analysis confirms that in the case of Polish officials, socialising into various contexts within the Council, changes regarding their properties do not resemble a deep shift of loyalty away from the national government. The interviewees asserted that they see state interest as their primary goal and recognise that 'every decision must be "sold" at home' (Interview 1). Some of them claimed to be in 
contact with the capital if negotiations become difficult (in a difficult situation (...) you need to consult with the capital' - Interview 8), but others emphasised they 'have a lot of freedom' (Interview 10). One of the interviewees admitted that sometimes the representatives do not fully identify with the position they have to represent, but it 'would be unprofessional' to make such attitude visible (Interview 1). Moreover, some of the Council norms seem to have a positive impact on an effective representation of national positions and thus on the indirect legitimisation of Council decision-making. One of the participants claimed that a member state will get its way if 'there is a justified interest behind its position (...) regardless of the quality of argumentation or if that interest is reconcilable with common [EU] interest' (Interview 2).

There are, however, norms which could disrupt representation. First, there seems to be a bias against outlier positions, irrespective of other considerations - 'extreme positions are dismissed' (Interview 3). Second, and related, there is a norm against objecting. This norm appears to be socially sanctioned, both at individual and state levels. Interviewees admitted that 'no one wants to be the vetoing party, so as to avoid being seen as the one blocking initiatives' (Interview 6). States become less successful in negotiations if they attract the opinion of 'staying in the way' (Interview 5). One must 'swallow one's pride' to avoid being seen as 'the brakeman' (Interview 1). 'The corridors are unforgiving', claims one of the officials, saying that is why you cannot be 'the spoiler' (Interview 1).

These norms couple with another consideration, that of insufficient resources. The size of the administration matters: ('Small administrations are not able to process everything' Interview 3), as does the time at the disposal of capitals and ministers; the latter 'do what is written for them in the papers' (Interview 2). While 'the papers' are prepared by Brusselsbased officials, one could argue that they themselves receive instructions from their capitals. Instructions are the formal way in which national positions move to the supranational level, and as such can be seen as the crucial instrument for providing indirect legitimacy to the decision-making process in the Council. Most of my interviewees did not see the instructions as strict, inflexible directives, though, and admitted that 'in the evolving debate [they] go beyond instructions' (Interview 8) or even claimed that they 'would not get anywhere if [they] always stuck to the instructions' (Interview 9). They expressed frustration with bad instructions, i.e. when they encountered what they identify as ignorance on the part of their domestic administration: 'when things do not go according 
to our [government's] vision, we [in the working parties] are between a rock and a hard place' (Interview 3). This leads the officials to reinterpret their instructions or openly distance themselves from them in front of their colleagues (' $\mathrm{I}$ sometimes separate the position from myself - Interview 3; 'Sometimes it is apparent that the ambassador has a different idea than the one he presents' - Interview 1). Occasionally officials actively undermine their instructions - admitting informally, in the corridors, they 'have to deliver such and such statement' (Interview 10) but their government will back down if colleagues from other countries press them, so that they can report to the capital that they were alone and would be outvoted.

One additional factor has to do with transparency, or rather the lack thereof. According to one the interviewees, transparency would undermine the ability of the EU to decide, because it would make representatives of the member states, the European Parliament, and others, less flexible with their positions ('individuals will hold their starting position more strongly (...) This will kill many decision-making processes' - Interview 1).

To summarise this part of the analysis, both positive and negative factors for legitimacy intermediation can be found in the practices of national officials in the Council. However, while they remain generally loyal to their governments, the strong norms against 'being the brakeman' make them less reliable as neutral intermediaries of national positions than the typical pro-indirect legitimacy argument assumes. They go beyond their instructions, reinterpret their mandate and even occasionally undermine the positions of their government in order to reach a reasonable solution, which they can 'sell' to their superiors, at the same time avoiding negative social consequences within the Council.

Significant portions of the interviews were devoted to the ways of reaching decision in the preparatory bodies of the Council, especially the extent to which they are consensual and how are they affected by qualified majority rule. One of the recurring notions was that there is a willingness within the Council to include particular needs of the member states, that there is an attitude of openness and 'a recognition of unique situations, understanding when someone has a problem [with particular proposal]' (Interview 6). In fact, 'when someone has a problem with a rigid position' (Interview 6), especially when it is known that 'something is very important to them' (Interview 9), others attempt to address their reservations, 'to meet them' (Interview 5). 
In broader terms, interviewees referred to 'a spirit of compromise' in the Council (same phrase used in Interview 8 and Interview 10) and emphasised that 'you can always get along' (Interview 7). They also stated that the decision-making culture in the Council prohibits humiliating the minority ('there is no culture of humiliation' - Interview 2). It is important to ensure that 'no one is a loser' (Interview 1), so even if there is a qualified majority for a proposal, the presidency tries to 'meet the expectations of a minority' (Interview 9). In this environment, it is crucial whether there is an important, justified interest or problem behind a position or not ('It is crucial to present your own circumstances' - Interview 4) and whether it is properly explained: 'argumentation is important (...), there is a genuine discussion, an argument-based dispute' (Interview 6). The argumentation 'is rather for than against' (Interview 2), which fits with the bias against opposing described above. The level of confrontation is low, manifest in the language used. Multiple interviewees described how even the negative statements were always softened with some positive message at the beginning (similar descriptions present in: Interview 3; Interview 8; Interview 9; Interview 10).

It is interesting how the interviewees described decision-making under qualified majority voting rule. One said, 'it essentially is a consensus, but of a different kind, which demands more flexibility' (Interview 10). Another assured that, regardless of qualified majority threshold being achieved or not, the objective of negotiation is to 'reach consensus' or at least 'consensus minus one' (Interview 5). According to one of the interviewees, consensus is a legitimating instrument, which 'expresses the sovereignty of the member states' (Interview 3). On the other hand, another official claimed that both the secretariat and the presidency continuously monitor the (hypothetical) distribution of votes and focus their efforts on eliminating blocking minorities ('From the very beginning, the secretariat and the presidency calculate qualified majority and blocking minority' Interview 1).

Moving towards the delegitimating facets of consensus, the primary problem, as described above, is whether consensus is in fact a genuine compromise or only a pretence. One interviewee defined consensus as follows: 'consensus does not mean that everyone agrees, but they know what is the blocking minority threshold and will not be voting against in vain - instead they try to earn small concessions' (Interview 2). What follows is that some states might remain deeply dissatisfied with the compromise, but due to different 
pressures their representatives will not express the dissatisfaction, tacitly accepting 'consensual' decisions.

Another feature of the EU decision-making worth some attention in this context is the content of decisions. Interviewees said that consensus was often 'a rotten compromise', which stemmed from the effort to 'reach consensus by all means' (Interview 6). They claimed that the content of decisions was purposefully written 'ambiguously, with shades of grey' (Interview 4) - such 'European compromise is based on ambiguity which reconciles the parties' (Interview 7). One interviewee observed that this kind of compromise might be useless and cause problems with interpretation in the future (Interview 10).

To summarise, there are mixed results of my analysis regarding the influence of socialisation on the character of consensus in the Council. While several quotations included above suggest that consensus might be accepted even if it is false or ambiguous, there is no trace of domination by powerful member states or supranational actors. Moreover, there is evidence showing how the normative environment of the Council in fact supports the inclusion of genuine concerns the member states might have, regardless of their voting power. By making interactions softer and more open, socialised behaviours and norms foster the approach to compromise aimed at ensuring there are no big losers. In this way socialisation might support output legitimacy, and also to some extent the indirect input legitimacy of the decision-making process in the Council.

\section{Conclusions}

This article was an inquiry into the ways socialisation of national officials in the Council of the European Union could enhance or undermine the legitimacy of the decision-making process in which they take part. Its point of departure was establishing the complex, opaque and consensual character of the process. The exploratory analysis of interview material followed, meant to answer two main questions - one related to the potential disruption of input legitimacy intermediation through the Council, the other focused on whether consensual practices in the Council provide output legitimacy.

As the results show, there is no simple answer to either of these questions - there are diverse ways in which national officials adopt norms and adapt to behaviours expected of 
them. However, it is possible to distinguish some tendencies or more prevalent practices among socialised officials, evident from the empirical material analysed.

National officials remain loyal to their governments, but they tend to accept norms against objecting or presenting outlier positions. They reinterpret their instructions and attempt to reach solutions acceptable to both their capitals and their colleagues within the Council. This way, socialisation can be seen as disruptive to legitimacy intermediation through the Council.

There is no evidence for norms sustaining the domination of the strongest players in the Council. The normative environment supports the inclusion of justified requests made by national representatives, regardless of the share of votes at their disposal. Even though consensus is sometimes false, socialised behaviours and norms favour genuine compromise aimed at ensuring there are no big losers among the member states. Socialisation can thus be said to support the provision of output legitimacy to the decision-making process in the Council.

It is important to note that both sets of socialised norms and behaviours are interrelated. Genuine consensus depends on member state representatives' willingness to transcend their mandates and refrain from objecting, in favour of constructive input. Coming back to Figure 1, the scenario in the top right corner is what the empirical material analysed in this paper supports. However, this does not mean that each Council decision necessarily lacks input legitimacy or is well-legitimised on the output side. This article analysed the influence of socialisation and does not argue for an absence of other factors which work for or against the legitimacy of decision-making in the Council.

Currently, more effort is invested into reaching a more inclusive compromise in the Council than one would expect if it were to decide by qualified majority. If national parliaments get more involved and transparency is introduced, the practices of consensus might weaken, because the governments of the powerful member states would be obliged to vote against other states rather than reach a compromise solution. Such a development could either halt legislation or institute a system of domination by the strongest member states.

More research is needed in particular into the practice of consensus. While the puzzle of consensus in the Council has received considerable attention and a number of explanations, underpinned by various theoretical standpoints, none is clearly more 
persuasive than others (cf. Lawniczak 2015: 133-134). Moreover, they focus on general logics or mechanisms, in which the participants of the negotiation process play their prescribed roles and are analytically deprived of agency. This paper focused on the practical reality of work in the Council, as accessed through in-depth interviews. Embracing interpretive methodology and moving closer towards the meaning of consensus, as it is enacted by national officials, would provide a richer understating of consensus. This could help to develop existing explanations of consensus, as well as deepen the understanding of the problems related to legitimacy presented in this article.

\footnotetext{
* Institute of European Studies, Faculty of Political Science and International Studies, University of Warsaw. Research was conducted within the project Socialisation mechanisms in the decision-making process in the Council of the European Union financed by the Polish National Science Centre, grant agreement no. UMO2013/09/N/HS5/00065. First draft of this paper was presented at the conference EU Legitimacy in Time of Crisis: How to Overcome the Legitimacy and Democracy Deficit of the EU?, 20-21 June 2016, Warsaw.

I Ana Juncos and Karolina Pomorska (2011: 1106) argue that consensual decision-making is dependent on the lack of transparency.

References
}

- Aus Jonathan P., 2010, 'The Mechanisms of Consensus: Coming to Agreement on Community Asylum Policy', in Daniel Naurin and Helen Wallace (eds), Unveiling the Council of the European Union. Games Governments Play in Brussels, Palgrave, Basingstoke, 99-118.

- Beyers Jan, 2010, 'Conceptual and Methodological Challenges in the Study of European Socialization', Journal of European Public Policy, XVII(6): 909-920.

- Beyers Jan and Dierickx Guido, 1998, 'The working groups of the Council of the European Union: supranational or intergovernmental negotiations?', JCMS: Journal of Common Market Studies, XXXVI(3): 289317.

- Checkel Jeffrey T., 2007, 'International institutions and socialization in Europe: introduction and framework', in Jeffrey T Checkel (ed), International Institutions and Socialization in Europe, Cambridge University Press, Cambridge, 3-27.

- Chelotti Nicola, 2016, 'Transgovernmental networks and rationalist outputs? The partial social construction of EU foreign policy', European Security, XXV(4): 524-541.

- Clark Julian and Jones Alun, 2011, “Telling Stories about Politics": Europeanization and the EU's Council Working Groups', JCMS: Journal of Common Market Studies, XLIX(2): 341-366.

- Cross James P., 2012, 'Interventions and negotiation in the Council of Ministers of the European Union', European Union Politics, XIII(1): 47-69.

- Cross James P., 2013, 'Striking a pose: Transparency and position taking in the Council of the European Union', European Journal of Political Research, LII(3): 291-315.

- Dehousse Renaud, Fernández Pasarín Ana Mar, and Pere Plaza Joan, 2014, 'How consensual is comitology?', Journal of European Public Policy, XXI(6): 842-859.

- Drulák Petr, Ĉesal Jirí, and Hampl Stanislav, 2003, 'Interactions and identities of Czech civil servants on their way to the EU', Journal of European Public Policy, X(4): 637-654.

- Fabbrini Sergio, 2016, 'From consensus to domination: the intergovernmental union in a crisis situation', Journal of European Integration, XXXVIII(5): 587-599.

- Fabbrini Sergio and Puetter Uwe, 2016, 'Integration without supranationalisation: studying the lead roles of the European Council and the Council in post-Lisbon EU politics', Journal of European Integration, XXXVIII(5): 481-495. 
- De Fine Licht Jenny, Naurin Daniel, Esaiasson Peter, and Gilljam Mikael, 2014, 'When Does Transparency Generate Legitimacy? Experimenting on a Context-Bound Relationship', Governance, XXVII(1): 111-134.

- Føllesdal Andreas and Hix Simon, 2006, 'Why There is a Democratic Deficit in the EU: A Response to Majone and Moravcsik', JCMS: Journal of Common Market Studies, XLIV(3): 533-562.

- Grøn Caroline Howard and Salomonsen Heidi Houlberg, 2015, 'Who's at the table? An analysis of ministers' participation in EU Council of Ministers meetings', Journal of European Public Policy, XXII(8): 10711088.

- Häge Frank Michael, 2008, 'Who Decides in the Council of the European Union?', JCMS: Journal of Common Market Studies, XLVI(3): 533-558.

- Häge Frank Michael, 2013, 'Coalition Building and Consensus in the Council of the European Union', British Journal of Political Science, XLIII(3): 481-504.

- Heisenberg Dorothee, 2005, "The institution of "consensus" in the European Union: Formal versus informal decision-making in the Council', European Journal of Political Research, XLIV(1): 65-90.

- Hillebrandt Maarten Zbigniew, Curtin Deirdre, and Meijer Albert, 2014, 'Transparency in the EU Council of Ministers: An Institutional Analysis', European Law Journal, XX(1): 1-20.

- Hillebrandt Maarten Zbigniew and Novak Stéphanie, 2016, “Integration without transparency”? Reliance on the space to think in the European Council and Council', Journal of European Integration, XXXVIII(5): 527-540.

- Høyland Bjørn and Hansen Vibeke Wøien, 2014, 'Issue-specific policy-positions and voting in the Council', European Union Politics, XV(1): 59-81.

- Interview 1-10, see Appendix.

- Juncos Ana E. and Pomorska Karolina, 2011, 'Invisible and unaccountable? National Representatives and Council Officials in EU foreign policy', Journal of European Public Policy, XVIII(8): 1096-1114.

- Kaniok Petr, 2016, 'In the shadow of consensus: Communication within council working groups', Journal of Contemporary European Research, XII(4): 881-897.

- Kirpsza Adam, 2011, 'Rada Ministrów bez ministrów? Wpływ struktury organizacyjnej Rady Unii Europejskiej na kształt procesu podejmowania decyzji: perspektywa konstruktywizmu społecznego', Studia Europejskie, (4): 9-32.

- Kleinowski Marcin, 2012, 'Konsensualne negocjacje czy głosowanie - kontestowanie aktów prawnych w Radzie UE', Studia Europejskie, (4): 27-50.

- König Thomas and Junge Dirk, 2010, 'Veto Players Theory and Consensus Behaviour', in Daniel Naurin and Helen Wallace (eds), Unveiling the Council of the European Union. Games Governments Play in Brussels, Palgrave, Basingstoke, 81-98.

- Laursen Bo, 2013, 'Transparency in the Council of the European Union: Why journalists don't get the full picture', Journalism, XIV(6): 771-789.

- $\quad$ Lawniczak Kamil, 2015, 'Socialisation and decision-making in the Council of the European Union', Przeglad Europejski, XXXVIII(4): 122-140.

- Lewis Jeffrey, 2007, 'The Janus face of Brussels: socialization and everyday decision making in the European Union', in Jeffrey T Checkel (ed), International Institutions and Socialization in Europe, Cambridgr University Press, Cambridge, 137-169.

- Lewis Jeffrey, 2010a, 'Strategic Bargaining, Norms, and Deliberation', in Daniel Naurin and Helen Wallace (eds), Unveiling the Council of the European Union. Games Governments Play in Brussels, Palgrave, Basingstoke, 165-184.

- Lewis Jeffrey, 2010b, 'How institutional environments facilitate co-operative negotiation styles in EU decision-making', Journal of European Public Policy, XVII(5): 648-664.

- Lord Christopher, 2009, 'Polecats, Foxes and Lions. Social Choice, Moral Philosophy and the Justification of the European Union as a Restrained yet Capable form of Political Power', ARENA Working Paper, (15)

- Majone Giandomenico, 1998, 'Europe’s “Democratic Deficit”: The Question of Standards', European Law Journal, IV(1): 5-28. 
- Mattila Mikko, 2010, 'Voting and Coalitions in the Council after the Enlargement', in Daniel Naurin and Helen Wallace (eds), Unveiling the Council of the European Union. Games Governments Play in Brussels, Palgrave, Basingstoke, 23-35.

- Moravcsik Andrew, 2002, 'In Defence of the "Democratic Deficit": Reassessing Legitimacy in the European Union’, JCMS: Journal of Common Market Studies, XL(4): 603-624.

- Moravcsik Andrew, 2008, 'The Myth of Europe’s "Democratic Deficit”, Intereconomics, XLIII(6): 331340.

- Naurin Daniel, 2009, 'Most Common When Least Important: Deliberation in the European Union Council of Ministers', British Journal of Political Science, XL(1): 31-50.

- Naurin Daniel, 2015, 'Generosity in intergovernmental negotiations: The impact of state power, pooling and socialisation in the Council of the European Union', European Journal of Political Research, LIV(4): 726-744.

- Naurin Daniel and Lindahl Rutger, 2010, 'East-North-South: Coalition-Building in the Council Before and After Enlargement', in Daniel Naurin and Helen Wallace (eds), Unveiling the Council of the European Union. Games Governments Play in Brussels, Palgrave, Basingstoke, 64-78.

- Niemann Arne, 2010, 'Deliberation and Bargaining in the Article 113 Committee and the 1996/97 IGC Representatives Group', in Daniel Naurin and Helen Wallace (eds), Unveiling the Council of the European Union. Games Governments Play in Brussels, Palgrave, Basingstoke, 121-143.

- Novak Stéphanie, 2013, 'The Silence of Ministers: Consensus and Blame Avoidance in the Council of the European Union', JCMS: Journal of Common Market Studies, LI(6): 1091-1107.

- Orbell John M., Van de Kragt Alphons J., and Dawes Robyn M., 1988, 'Explaining discussioninduced cooperation.', Journal of Personality and Social Psychology, LIV(5): 811-819.

- Payton, Autumn Lockwood, 2010, 'Consensus Procedures in International Organizations', EUI Working Papers MWP, (22): 1-20.

- Puetter Uwe, 2016, 'The centrality of consensus and Deliberation in Contemporary EU Politics and the new intergovernmentalism', Journal of European Integration, XXXVIII(5): 601-615.

- $\quad$ Reh Christine, 2014, 'Is informal politics undemocratic? Trilogues, early agreements and the selection model of representation', Journal of European Public Policy, XXI(6): 822-841.

- Reh Christine, Héritier Adrienne, Bressanelli Edoardo, and Koop Christel, 2013, 'The Informal Politics of Legislation', Comparative Political Studies, XLVI(9): 1112-1142.

- Risse Thomas and Kleine Mareike, 2010, 'Deliberation in negotiations', Journal of European Public Policy, XVII(5): 708-726.

- Roederer-Rynning Christilla and Greenwood Justin, 2015, 'The culture of trilogues', Journal of European Public Policy, XXII(8): 1148-1165.

- Scharpf Fritz W., 2006, 'Problem solving effectiveness and democratic accountability in the EU', Political Science Series, (107).

- $\quad$ Scharpf Fritz W., 2007, 'Reflections on Multilevel Legitimacy', MPIfG Working Paper, (3).

- $\quad$ Scharpf Fritz W., 2009, 'Legitimacy in the Multilevel European Polity', MPIfG Working Paper, (1).

- $\quad$ Schmidt Vivien Ann, 2006, Democracy in Europe. The EU and national polities, Oxford University Press, Oxford.

- Schwartz-Shea Peregrine and Yanow Dvora, 2012, Interpretive Research Design. Concepts and Processes, Routledge, New York.

- Smeets Sandrino, 2015, 'Unanimity and exposure in the EU Council of Ministers - or how the Dutch won and lost the ICTY debate', European Journal of Political Research, LIV(2): 288-304.

- Smeets Sandrino, 2016, 'Consensus and Isolation in the EU Council of Ministers', Journal of European Integration, XXXVIII(1): 23-39.

- Thomson Robert, 2010, 'The Relative Power of Member States in the Council: Large and Small, Old and New', in Daniel Naurin and Helen Wallace (eds), Unveiling the Council of the European Union. Games Governments Play in Brussels, Palgrave, Basingstoke, 238-258.

- Trondal Jarle, 2004, 'Re-Socializing Civil Servants: The Transformative Powers of EU Institutions', Acta Politica, XXXIX(1): 4-30. 
- $\quad$ Tsebelis George, 2013, 'Bridging qualified majority and unanimity decisionmaking in the EU', Journal of European Public Policy, XX(8): 1083-1103.

- Warntjen Andreas, 2010, 'Between bargaining and deliberation: decision-making in the Council of the European Union', Journal of European Public Policy, XVII(5): 665-679.

- Warntjen Andreas, 2017, 'Why no Gridlock? Coping with Diversity in the Council of the European Union', Journal of Contemporary European Research, XIII(1): 963-979.

\section{Appendix - Interview scenario}

The interviews were conducted between March and September 2015 in Brussels (7 interviews) and Warsaw (3 interviews). All interviews were conducted in Polish, each took from one to two hours. Detailed notes were made during interviews. The following interview scenario was applied, with additional questions asked ad hoc in order to clarify or deepen particular topics.

The interview consisted of five parts. In the first I presented my research and the purpose of the interview, and then answered any doubts or questions of the interviewee. The second part served to provide information about the professional experience of the interviewee - how long they had been working in the Council, in which organs, how often their meetings were held, and what their responsibilities were. When the interlocutor worked in more than one body, they were asked at this point about the differences they observe between them. The third part of the interview was aimed at the self-definition of the interviewee, defining the role they play in the Council. Taking into account the answers, I asked questions about the relative importance of personal qualities, social relations and the represented state for the perception of an official by others in the Council's preparatory bodies, and what influence an official has on the negotiation process. The fourth part of the interview was a discussion of the changes that take place in the people working in the Council, with the passing of time and the gaining of experience - whether there are differences between the novices and the experienced at all and, if so, what they are and how they manifest. I asked, among other things, about the formation of social ties and their character, the ways of coping with problems, and the attitude towards the instructions which officials get from their capitals. The last section of the interview was the most open and attempted to let interviewees describe particular events from their experience. I asked them to describe the course of a meeting or course of a case, preferably one not in line with expectations. In addition, I asked about the process of reaching compromise with formal rules of unanimity and qualified majority voting. 